\title{
Efektivitas Pengembangan Modul Berbasis Proyek pada Mata Kuliah Kewirausahaan Akademi Komunitas Negeri Pesisir Selatan
}

\section{Widya Natalia ${ }^{1 *}$, Nizwardi Jalinus ${ }^{2}$}

1,2 Universitas Negeri Padang, Padang, Indonesia

\section{ART I C LE IN F O}

\section{Article history:}

Received September 26, 2021

Revised September 28, 2021

Accepted December 19, 2021

Available online December 25, 2021

Kata Kunci:

Modul, Project Based Learning Efektivitas

\section{Keywords:}

Modules, Project Based Learning, Effectiveness

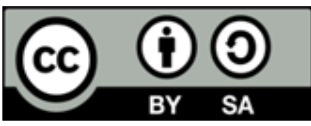

This is an open access article under the CC BY-SA license.

Copyright (@) 2021 by Author. Published by Universitas Pendidikan Ganesha.

\begin{abstract}
A B S T R A K
Belum tersedianya modul yang sistematis pada mata kuliah Kewirausahaan di Program Studi Teknik Fabrikasi dan Pengelasan Logam (TFPL) serta hasil belajar peserta didik belum optimal. Penelitian ini bertujuan untuk mengembangkan modul pembelajaran dan menghasilkan modul yang valid, praktis dan efektif pada mata kuliah Kewirausahaan berbasis proyek untuk peserta didik Program Studi TFPL di Akademi Komunitas Negeri Pesisir Selatan. Penelitian ini menggunakan metode Research and Development (penelitian dan pengembangan), dengan model pengembangan 4D. Prosedur pengembangan 4D yaitu Define (pendefinisian), Design (Perancangan), Develop (Pengembangan) dan Disseminate (Penyebaran). Teknik analisa data efektivitas dengan memakai skor $N$ Gain. Hasil yang diperoleh dari penelitian pengembangan ini untuk efektivitas modul pembelajaran diperoleh dari nilai pretest dan posttest mahasiswa setelah menggunakan modul pembelajaran berada dalam kategori efektif. Kesimpulannya modul pembelajaran berbasis proyek yang dikembangkan dapat digunakan pada proses pembelajaran untuk meningkatkan hasil belajar peserta didik.
\end{abstract}

\begin{abstract}
A B S T R A C T
The motion system material in humans is interesting for students, but this material is difficult to reach. Learners have not fully implemented the benefits of learning the motion system material in humans. It affects the low student learning outcomes. This study aims to produce visual learning media using Canva on Motion System materials. 2 experts and 1 teacher validated visual learning media to test its practicality. The methods used to collect data are observation, interviews, and questionnaires. The instrument used to collect data is a questionnaire. The technique used in data analysis is descriptive qualitative and quantitative analysis. As a result, visual learning media using Canva has been developed using 3 stages of the IDI model, namely the define stage, which aims to get an overview of conditions in the field by distributing student response questionnaires and teacher interviews, the development stage by designing visual learning media using Canva and validated by experts (validators). The evaluation phase aims to determine the extent of the benefits, convenience, and time efficiency of using media by teachers and students. The validity value is $89.68 \%$ with valid criteria, practicality by teachers is $91.87 \%$ with very valid criteria, and students with very valid criteria $90.06 \%$. The results of the study show that the video learning media using Canva is valid and practical for learning.
\end{abstract}

\section{PENDAHULUAN}

Pendidikan vokasi memegang peran sangat penting dan strategis dalam upaya mengatasi krisis tenaga kerja terampil karena tenaga kerja terampil dan berpendidikan akan lebih mudah dan cepat dicapai dengan pendidikan vokasi (Fataron \& Sijabat, 2019; Solikin, 2018). Pengembangan pembelajaran dalam penyelenggaraan pendidikan vokasional harus dilakukan oleh para pengelolanya terutama dari segi guru atau dosen sebagai pendidiknya agar kualitas lulusannya sesuai tuntutan lapangan kerja (Basri \& Dwiningrum, 2020; Nurcahyo \& Kartowagiran, 2015). Adanya Hubungan antara institusi atau dunia pendidikan vokasional dengan dunia kerja adalah hal yang penting agar dapat menciptakan lulusan yang 
profesional. Pendidikan vokasi saat ini harus mampu mengantisipasi dan menghadapi perubahan yang terjadi, karena tantangan di dunia kerja dengan kompetensi kerja yang makin tinggi seiring dengan kemajuan teknologi dan dinamika tempat kerja (Maulana \& Hamidi, 2020; Sumarmi \& Rostini, 2019).

Program Studi Diluar Domisili (PDD) Politeknik Negeri Padang Rintisan Akademi Komunitas Negeri Pesisir Selatan berperan aktif dalam pengembangan pendidikan vokasi. Akademi Komunitas Negeri Pesisir Selatan adalah perguruan tinggi sebagai lembaga pendidikan yang mempunyai misi menghasilkan lulusan yang terampil, berdaya saing, berjiwa entrepreneur dan bermartabat. Akademi Komunitas Negeri Pesisir Selatan merupakan Perguruan Tinggi dengan penyelenggaraan pendidikan kejuruan selevel diploma dua dalam satu atau beberapa cabang teknologi dan ilmu pengetahuan tertentu berdasarkan keunggulan lokal (daerah) atau untuk memenuhi sesuatu kebutuhan yang khusus. Teknik Fabrikasi dan Pengelasan Logam, Teknik Perawatan dan Perbaikan Mesin Kapal merupakan program studi pada jurusan Teknik Mesin yang dimiliki oleh Akademi Komunitas Negeri Pesisir Selatan. Selain itu Akademi Komunitas Negeri Pesisir Selatan juga memiliki program studi Manajemen Informatika. Pada Akademi Komunitas Jurusan Teknik terdapat beberapa mata kuliah yang wajib dipelajari oleh semua peserta didik. Mata kuliah Kewirausahaan adalah salah satu mata kuliah yang harus dipelajari oleh mahasiswa tersebut.

Namun kenyataanya, berdasarkan pengamatan pada mata kuliah kewirausahaan dan wawancara kepada peserta didik diperoleh informasi bahwa kelemahan peserta didik, antara lain kemampuan analisis peserta didik tentang mata kuliah masih belum optimal. Hal tersebut menyebabkan pendidik kesulitan untuk menyampaikan materi pembelajaran, sehingga tujuan pembelajaran masih belum tercapai karena masih rendahnya kemampuan peserta didik dalam mengaplikasikan teori yang dipelajari terhadap kehidupan nyata. Salah satu penyebahnya adalah karena kurang menariknya pelaksanaan proses pembelajaran dan kurangnya sumber belajar yang pakai oleh peserta didik. Faktor lain yang menyebabkan rendahnya hasil belajar dan kemampuan peserta didik dalam menerapkan konsep kewirausahaan adalah metode mengajar masih didominasi menggunakan metode ceramah. Metode ceramah hanya menghandalkan penjelasan dari pendidik sehingga peserta didik tidak terlibat secara aktif dalam proses pembelajaran. Keadaan ini mengakibatkan sebagian peserta didik jenuh dengan suasana belajar, karena peserta didik hanya mendengarkan pendidik di kelas, selain itu mengurangi minat dan motivasi peserta didik dalam memahami mata kuliah. Bahan pembelajaran yang digunakan masih konvensional dan perlu dilakukan improvisasi. Modul pada mata kuliah Kewirausahaan berbasis proyek ini belum ada sebelumnya di program studi TFPL jurusan Teknik Mesin Akademi Komunitas Negeri Pesisir Selatan.

Salah satu cara yang dapat dilakukan untuk mengatasi masalah ini adalah dengan pendidik merancang modul ajar dengan sebuah model pembelajarann. Ini bertujuan supaya peserta didik mudah menerima pelajaran dan pembelajaran menjadi bermakna. Model Project Based Learning (PjBL) cocok digunakan dalam pembelajaran Kewirausahaan di Prodi TFPL Akademi Komunitas Negeri Pesisir Selatan. Salah satu alternatif model pembelajaran yang memungkinkan dikembangkannya keterampilan berpikir peserta didik (penalaran, komunikasi, dan koneksi) dalam memecahkan masalah adalah Project Based Learning (PjBL) (Akbar \& Bahri, 2017; Lutfi et al., 2017; Safitri et al., 2018). Modul pembelajaran PjBL mata kuliah Kewirausahaan diharapkan mampu menjadi solusi pada proses pembelajaran ini. PjBL merupakan sebuah strategi pembelajaran menggunakan proyek sebagai sarana pencapaian kompetensi (Saputro \& Rayahu, 2020; Triana et al., 2020). Model project based learning adalah model pembelajaran yang memberikan kesempatan kepada guru untuk mengelola pembelajaran di kelas dengan melibatkan kerja proyek (Fiana et al., 2019; Mahendra, 2017; Setyowati \& Mawardi, 2018). Kerja proyek memuat tugas-tugas yang kompleks berdasarkan permasalahan (problem) yang diberikan kepada siswa sebagai langkah awal dalam mengumpulkan dan mengintegrasikan pengetahuan baru berdasarkan pengalamannya dalam beraktivitas secara nyata, dan menuntut siswa untuk melakukan kegiatan merancang, melakukan kegiatan investigasi atau penyelidikan, memecahkan masalah, membuat keputusan, serta memberikan kesempatan kepada siswa untuk bekerja secara mandiri maupun berkelompok (kolaboratif) (Bai, 2019; Logan et al., 2021; Marlani \& Prawiyogi, 2019).

\section{METODE}

Penelitian ini menggunakan metode Research and Development (penelitian dan pengembangan men). Metode penelitian dan pengembangan adalah metode penelitian yang digunakan untuk menghasilkan produk tertentu dan menguji keefektifan produk tersebut (Sugiono, 2018). Pengembangan yang digunakan adalah model pengembangan 4D (four- $D$ models). Model pengembangan terdiri empat tahap (four- $D$ models) pengembangan, ialah define (mendefinisikan), design (merancang), develop (mengembangkan) dan disseminate (menyebarkan). Model four- $D$ ini memiliki kelebihan antara lain model 4D mengakhiri kegiatan melalui kegiatan dissemination, model 4D tidak menampilkan kegiatan implementasi dan evaluasi, hal ini disebabkan pada tahap development kegiatannya selalu menyertakan pembuatan produk (implementasi), 
revisi dan evaluasi. Pada penelitian pengembangan ini yang menjadi subjek untuk uji coba ialah peserta didik angkatan 2018 sebanyak 22 orang Program Studi TFPL Jurusan Teknik Mesin Akademi Komunitas Negeri Pesisir Selatan yang mengambil mata kuliah Kewirausahaan. Subjek uji coba produk bertujuan sebagai sumber pengumpulan data-data yang berkenaan dengan kualitas dari modul project-based learning, untuk mencapai standar kompetensi yang efektif, dan melihat respon subjek uji coba terhadap produk yang telah dikembangkan dalam proses pembelajaran. Teknik analisa data yang dipakai pada penelitian ini merupakan teknik analisa data deskriptif, yakni dengan mendeskripsikan data keefektifan dalam penggunaan modul Kewirausahaan dengan metode project-based learning. Teknik analisis data yang digunakan analisis kuantitatif dan kualitatif. Untuk melihat hasil belajar dari peserta didik digunakan soal pretest dan posttest. Analisis peningkatan hasil belajar dari pretest dan postest memakai skor N-Gain.

\section{HASIL DAN PEMBAHASAN}

Hasil

Pengembangan yang digunakan adalah model pengembangan 4D (four- $D$ models). Model pengembangan terdiri empat tahap (four-D models) pengembangan, ialah define (mendefinisikan), design (merancang), develop (mengembangkan) dan disseminate (menyebarkan). Tahap Define (pendefinisian), langkah pendefinisian bertujuan mendefinisikan dan menetapkan persyaratan dalam pembelajaran. Tahapan ini menganalisa kebutuhan yang diperlukan untuk proses pembuatan modul Kewirausahaan. Langkah-langkah yang dilakukan observasi, observasi mempunyai tujuan mengetahui permasalahan, hambatan-hambatan serta fenonema yang terjadi di lapangan sehubungan dengan mata kuliah Kewirausahaan. Permasalahan dan hambatan-hambatan ini bisa berasal dari peserta didik ataupun pendidik. Observasi dilakukan di Program Studi Teknik Fabrikasi dan Pengelasan Logam Jurusan Teknik Mesin di Akademi Komunitas Negri Pesisir Selatan pada mata kuliah Kewirausahaan diperoleh masalah dari pendidik dan peserta didik. Selanjutnya analisa kurikulum, analisis kurikulum dimaksudkan untuk menentukan materi pembelajaran yang dikembangkan modulnya. tahap ini dilakukan analisis mengenai standar kompetensi dan kompetensi dasar pada pembelajaran, indikator, silabus dan RPS, sehingga modul yang akan dikembangkan nantinya sesuai dengan tujuan yang akan dicapai dalam kompetensi dasar dan indikator tersebut. Analisis kurikulum ini dilakukan supaya produk modul berbasis proyek yang dihasilkan tidak menyimpang dari tujuan pembelajaran sesuai dengan silabus kurikulum yang diterapkan di Akademi Komunitas Negeri Pesisir Selatan. Selain itu, mempelajari karakteristik peserta didikk bertujuan agar memudahkan dalam pemberian kesempatan peserta didik untuk meningkatkan pengetahuan dan pemahaman dalam belajar, serta memudahkan penyusunan tingkat bahasa dalam modul Kewirausahaan. Dari analisis karakteristik peserta didik, bisa menentukan pendekatan yang tepat untuk dipakai dalam proses pembelajaran.

Kedua tahap design (Perancangan), merancang modul Kewirausahaan dengan model project based learning di Program Studi TFPL Jurusan Teknik Mesin dalam merancang pengembangan modul yaitu pemilihan format, ketersesuaian antara materi dengan silabus, modul yang dirancang disusun sesuai tuntutan RPS mata kuliah Kewirausahaan, tata bahasa yang dipakai, cara penyampaian materi yang berpengaruh dalam pengembangan modul pembelajaran Kewirausahaan dengan metode project based learning. Ketiga tahap develop (Pengembangan). Langkah pengembangan dilaksanakan untuk memperoleh produk (modul) yang valid, praktis dan efektif. Tahap validasi merupakan penilaian terhadap rancangan suatu produk. Validasi produk dilakukan oleh beberapa pakar atau tenaga ahli yang sudah berpengalaman terhadap produk, sehingga pakar/ahli tersebut dapat menilai kelemahan dan kekuatan dari produk yang dihasilkan. Validator dapat berupa pakar, teman sejawat, dan praktisi yang relevan. Proses validasi diperoleh masukan dari validator yang digunakan untuk merevisi modul yang dikembangkan. Masukan dari validator dijadikan pedoman dalam melakukan perbaikan dan revisi produk yang dibuat sebelum dilakukan uji coba.

Ketiga tahap praktikalitas, praktikalitas adalah taraf keterpakaian modul Kewirausahaan project based learning bagi peserta didik dan pendidik, yaitu dengan melakukan pembelajaran menggunakan modul yang sudah direvisi sesuai penilaian dari validator. Praktikalitas terkait dengan keterpakaian modul Kewirausahaan yang dapat diketahui dengan melakukan uji coba penggunaan modul yang telah dinyatakan praktis oleh praktisi. Kegiatan praktikalitas digunakan untuk memperoleh kemudahan, manfaat dan efisiensi dalam menggunakan modul oleh pendidik dan peserta didik. Pengujian praktikalitas dilakukan dengan memberikan angket praktikalitas pada peserta didik dan pendidik. Hasil dari angket akan dianalisa, dari analisa itu diperoleh kepraktisan penggunaan modul berdasarkan kriteria yang telah ditetapkan. Modul dapat dinyatakan mempunyai praktikalitas jika bersifat praktis, mudah dipahami dan mudah dalam menggunakannya. Hasil angket ini dijadikan sebagai pondasi dalam melakukan perbaikan terhadap modul yang dikembangkan. 
Keempat, tahap efektivitas. Tahap ini dilakukan jika modul project-based learning dinyatakan praktis. Tahap ini dipusatkan untuk mengevaluasi modul project-based learning agar dapat digunakan untuk mencapai tujuan yang efektif dalam meningkatkan kualitas dan prestasi belajar peserta didik. Tujuan belajar bisa tercapai dengan melihat hasil belajar atau nilai peserta didik dengan menguji cobakan produk kepada peserta didik. Penilaian atau hasil belajar terlihat berdasarkan hasil analisis pretest dan posttest serta penilaian hasil produk (aspek psikomotor). Hasil belajar merupakan aspek efektif yang bisa diamati pada proses belajar. Keefektifan produk yang dimaksud adalah akibat atau pengaruh dari modul pembelajaran terhadap kompetensi peserta didik setelah menggunakan modul. Ketuntasan klasikal dilihat dari persentase jumlah peserta didik yang tuntas setelah menggunakan modul pembelajaran. Dasar untuk menentukan efektivitas modul pembelajaran Kewirausahaan berbasis proyek adalah jika klasikal peserta didik diperoleh lebih besar atau sama dengan 85\% maka modul pembelajaran efektif digunakan. Jika sebaliknya, persentasi ketuntasan klasikal peserta lebih kecil dari 85\% maka modul pembelajaran tidak efektif digunakan. Berdasarkan hasil analisis, maka didapatkan jumlah peserta didik yang lulus sebanyak 20 orang (91\%), hal ini menunjukkan ketuntasan klasikal telah tercapai, dapat disimpulkan bahwa modul pembelajaran Kewirausahaan berbasis proyek efektif digunakan jika ditinjau dari ketuntasan klasikal. Efektivitas ditinjau dari analisis hasil pretest-posttest terjadi peningkatan rata-rata nilai peserta didik sebesar 23,00. Untuk analisis nilai gain score didapatkan nilai minimal adalah 16,67 dengan klasifikasi rendah, nilai gain score maksimal 71,43 dengan klasifikasi tinggi, dan nilai rata-rata dari gain score diperoleh sebesar 51,85 dengan klasifikasi sedang. Dengan perolehan peningkatan hasil belajar peserta didik sebesar 23,00 dan gain score bernilai dan 51,85 maka, efektivitas penggunaan modul Kewirusahaan bisa dikatakan sangat baik digunakan dalam kegiatan pembelajaran.

Keempat tahap disseminate (Penyebaran), langkah penyebaran adalah suatu tahap akhir dari pengembangan langkah 4-D yang ditawarkan, sesudah modul divalidasi dan pelaksanaan proses uji praktikalitas dan efektivitas suatu kelas tertentu, sehingga dihasilkan modul pembelajaran Kewirausahaan dengan metode project-based learning yang sudah valid, praktikalitas dan efektif. Penyebaran dapat dilakukan pada kelas lain dengan tujuan untuk mengetahui keterlaksanaan modul berbasis project-based learning dalam proses pembelajaran. Sebelum penguji cobaan terhadap modul pembelajaran yang dikembangkan maka perlu dilakukan revisi modul pembelajaran. Berdasarkan hasil diskusi dan saran dari validator, revisi terhadap modul pembelajaran dilakukan. Tujuan revisi produk untuk kesempurnaan pembelajaran Kewirausahaan sehingga menjadi modul pembelajaran yang valid, praktis dan efektif. Revisi/perbaikan dilaksanakan pada semua aspek, antara lain aspek desain modul pembelajaran, isi/materi, serta aspek Bahasa dapat dilihat pada Tabel 1,2,3.

Tabel 1. Revisi Modul Pembelajaran Aspek Desain

\begin{tabular}{cll}
\hline No & \multicolumn{1}{c}{ Sebelum Revisi } & \multicolumn{1}{c}{ Sesudah Revisi } \\
\hline 1 & Dalam PjBL diperlukan tugas proyek & Tugas proyek sudah dimasukkan \\
2 & $\begin{array}{l}\text { Pada cover tampilkan gambar yang } \\
\text { berhubungan materi }\end{array}$ & $\begin{array}{l}\text { Adanya gambar yang berhubungan dengan } \\
\text { materi }\end{array}$ \\
\hline
\end{tabular}

Tabel 2. Revisi Modul Pembelajaran Aspek Isi/Materi

\begin{tabular}{cll}
\hline No & \multicolumn{1}{c}{ Sebelum Revisi } & \multicolumn{1}{c}{ Sesudah Revisi } \\
\hline 1 & Tambahkan soal pada tugas & Soal sudah ditambahkan pada tugas \\
2 & Beri nama gambar & $\begin{array}{l}\text { Gambar sudah diberi nama } \\
\text { Gambar sudah ditampilkan sesuai materi yang } \\
\text { diberikan }\end{array}$ \\
\hline
\end{tabular}

Tabel 4. Revisi Modul Pembelajaran Aspek Bahasa

\begin{tabular}{cll}
\hline No & \multicolumn{1}{c}{ Sebelum Revisi } & \multicolumn{1}{c}{ Sesudah Revisi } \\
\hline 1 & Perbaiki Tata tulis & Tata tulis sudah diperbaiki \\
2 & Buat nomor Gambar & Gambar sudah dibuatkan nomornya \\
3 & Gunakan istilah baku & Sudah menggunakan istilah baku \\
\hline
\end{tabular}

\section{Pembahasan}

Pengembangan yang digunakan adalah model pengembangan 4D (four- $D$ models). Model pengembangan terdiri empat tahap (four-D models) pengembangan, ialah define (mendefinisikan), design (merancang), develop (mengembangkan) dan disseminate (menyebarkan). Dari tahapan tersebut modul berbasis project based learning dinyatakan layak dan valid. Hal ini dapat dilihat dari beberapa aspek. 
Pertama aspek materi, modul berbasis project based learning menyajikan materi yang sesuai dengan kurikulum, tujuan pembelajaran dan KD serta KI. Modul berbasis project based learning ini dapat memancing siswa mampu membuat peta konsep sendiri tentang materi yang dibelajarkan. Modul pembelajaran yang menarik juga dapat meningkatkan semangat serta motivasi siswa dalam belajar (Amini \& Oktarisma, 2021; Ramli \& Tajudin, 2021). Selain itu, pengembangan modul berbasis project based learning juga menyajikan gambar yang menarik bagi siswa. Hal ini sesuai dengan temuan penelitian sebelumnya yang menyatakan bahwa gambar yang menarik akan menarik serta memotivasi siswa dalam belajar (Aprinawati, 2017; Dames et al., 2019; Mardati et al., 2015). Modul berbasis project based learning yang dikemas baik akan meningkatkan ketertarikan siswa dalam belajar. Modul pembelajaran sesunguhnya memiliki peranan yang sangat penting dalam meningkatkan semangat siswa dalam belajar (Deviana, 2018; Yusnindar, 2015). Modul pembelajaran ini merupakan salah satu sarana yang dapat digunakan oleh guru jika siswa mengalami kesulitan dalam belajar. oleh karena itu pengembangan modul berbasis project based learning harus kreatif dan semenarik mungkin sehingga anak juga akan merasa tertarik dalam belajar (Devi \& Bayu, 2020; Fauzi et al., 2017; Khofiyah et al., 2019).

Kedua, modul berbasis project based learning layak diterapkan dalam proses pembelajaran karena memudahkan siswa dalam memahami materi pelajaran. Model pengembangan 4D digunakan karena berpijak pada pendekatan konstruktivisme, sehingga modul pembelajaran yang dihasilkan dengan menggunakan model ini dapat membantu siswa dalam membangun pengetahuannya secara mandiri. Pengembangan modul yang sesuai dengan karakteristik peserta didik akan memudahkan dalam memahami materi yang disajikan pada media (Gunawan et al., 2017; Sunismi, 2015; Trianawati, 2019). Modul berbasis project based learning yang dikembangkan membantu siswa dalam memecahkan masalah dan membuat keputusan terkait dengan masalah tersebut. Selain itu, penggunaan modul berbasis project based learning akan menyebabkan proses belajar yang menyenangkan dan mendorong anak untuk mandiri belajar serta sukses dalam prestasi akademiknya (Buran \& Filyukov, 2015; Rosciano, 2015). Perencanaan perkembangannya mengikuti sistem kerja otak, bersifat dinamis dengan beragam data visual, variasi tampilan dan pewarnaan (color full) dapat memudahkan siswa dalam memahami materi pelajaran (Kiong et al., 2012; Merchie \& Keer, 2016). Dapat disimpulkan bahwa modul berbasis project based learning yang dikemas dengan baik akan memudahkan siswa dalam memahami materi pelajaran.

Temuan ini diperkuat dengan penelitian sebelumnya yang menyatakan modul dapat meningkatkan aktivitas siswa dalam mengikuti pembelajaran (Hamdi, Halim \& Pontas, 2015; Jannah et al., 2021). Temuan lain juga menyatakan modul dengan berbasis model dapat membantu guru pada proses pembelajaran.(Kuncahyono, 2018; Suastika \& Amaylyla, 2019; Sudarmin \& Samini, 2016). Berdasarkan analisis yang dilakukan pada tahap uji efektifitas membuktikan penggunaan modul berbasis proyek dalam proses pembelajaran dapat membantu peserta didik dalam memahami materi lebih cepat dan meningkatkan interaksi antara guru dan peserta didik karena peserta didik sudah memiliki bekal dengan materi yang dibahas. Modul yang menyediakan teks yang ringan untuk dipahami, serta gambar yang lebih mendekati bentuk nyata dari sebuah komponen membantu peserta didik lebih mudah mengingat ketika komponen asli digunakan. Selain teks dan gambar yang mudah memberi pemahaman bagi peserta didik, video yang tersedia dalam modul juga memberi referensi bagi peserta didik dalam mengerjakan proyek yang mereka kerjakan (Sudarmin \& Samini, 2016; Utami et al., 2018). Modul yang dikembangkan dengan model project based learning membantu peserta didik lebih berperan aktif dalam pembelajaran, dengan proyek yang dikerjakan peserta didik membuat peserta didik lebih terlibat dalam mengikuti pembelajaran.

Model project based learning berpengaruh positif terhadap hasil belajar peserta didik dan mampu membantu peserta didik lebih aktif berpikir selama pembelajaran terutama dalam pembuktian suatu konsep berdasarkan pengamatan dan analisis yang mereka lakukan (Saputro \& Rayahu, 2020; Triana et al., 2020). Oleh karena itu model pembelajaran mbelajaran vektor dengan SD sesiri, buleleng nail. Temuan ini diperkuat, modul berbasis proyek pada mata kuliah kewirausahaan akademi komunit Modul pembelajaran berbasis proyek ini dikembangkan berdasarkan kondisi dan karakteristik peserta didik, harapannya peserta didik bisa dengan mudah memahami materi pelajaran. Temuan tersut menyatakan mudul efektif dan layak digunakan pada proses pembelajaran (Ismi, 2019).

\section{SIMPULAN}

Kesimpulan yang dapat ditarik dari pembahasan diatas adalah: hasil uji efektivitas modul pembelajaran Kewirausahaan diperoleh berdasarkan nilai pretest dan posttest dari peserta didik setelah menggunakan modul pembelajaran berada dalam kategori efektif. Modul pembelajaran Kewirausahaan berbasis proyek yang dikembangkan dapat dipakai dalam proses pembelajaran guna meningkatkan hasil belajar dari peserta didik. Pada umumnya karakter peserta didik lebih menyukai panduan dalam pembelajaran, dan menyukai tantangan yang diberikan dalam proses pembelajaran. Dengan menganalisis 
karakteristik peserta didik, peneliti bisa menentukan pendekatan yang tepat untuk diterapkan dalam proses pembelajaran.

\section{DAFTAR RUJUKAN}

Akbar, F., \& Bahri, A. (2017). Potensi Model PjBL (Project-Based Learning) dalam Meningkatkan Motivasi Belajar Peserta Didik dengan Gaya Belajar Berbeda. SAINSMAT, 6(1), 95 - 106. https://doi.org/10.35580/sainsmat6198902017.

Amini, Ri., \& Oktarisma, S. (2021). Pengembangan Modul Pembelajaran IPA Berbasis Picture and Picture di Sekolah Dasar. Jurnal Basicedu, 5(2), 835-841. https://doi.org/10.31004/basicedu.v5i2.769.

Aprinawati, I. (2017). Penggunaan Media Gambar Seri Untuk Meningkatkan Kemampuan Berbicara Anak Usia Dini. Jurnal Obsesi: Jurnal Pendidikan Anak Usia Dini, 1(1), 72. https://doi.org/10.31004/obsesi.v1i1.33.

Bai, L. D. Y. (2019). Comparison of Charity and Project-Based Service Learning Models on Knowledge Outcomes of Dietetic Students in a Community Nutrition Course. Journal of the Academy of Nutrition and Dietetics, 119(10), A124. https://doi.org/10.1016/j.jand.2019.08.082.

Basri, B., \& Dwiningrum, N. (2020). Peran Ormawa dalam Membentuk Nilai-nilai Karakter di Dunia Industri (Studi Organisasi Kemahasiswaan di Politeknik Negeri Balikpapan). Al-Adabiya: Jurnal Kebudayaan Dan Keagamaan, 15(01), 139-158. https://doi.org/10.37680/adabiya.v15i01.273.

Buran, A., \& Filyukov, A. (2015). Mind Mapping Technique in Language Learning. Procedia - Social and Behavioral Sciences, 206. https://doi.org/https://doi.org/10.1016/j.sbspro.2015.10.010.

Dames, I., Koeswanti, H. D., \& Radia, E. H. (2019). Penerapan Model Examples Non Examples Berbantuan Media Gambar Untuk Meningkatkan Hasil Belajar Pada Tema 1 Siswa Kelas 5 SDN Sidorejo Lor 05. Jurnal Basicedu, 3(2), 709-715. https://doi.org/10.31004/basicedu.v3i2.59.

Devi, P. S., \& Bayu, G. W. (2020). Berpikir Kritis dan Hasil Belajar IPA Melalui Pembelajaran Problem Based Learning Berbantuan Media Visual. MIMBAR PGSD Undiksha, 8(2), 238-252. https://doi.org/http://dx.doi.org/10.23887/jjpgsd.v8i2.26525.

Deviana, T. (2018). Analisis Kebutuhan Pengembangan Modul Pembelajaran Berbasis Kearifan Lokal Kabupaten Tulungagung Untuk Kelas V Sd Tema Bangga Sebagai Bangsa Indonesia. Jurnal

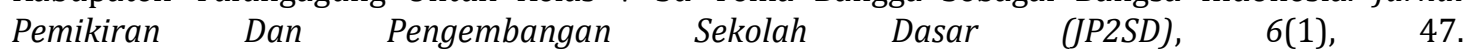
https://doi.org/10.22219/jp2sd.v6i1.5902.

Fataron, Z. A., \& Sijabat, R. (2019). The pathway of strengthening the working readiness: A study on graduate students of Islamic Economics and Business Faculty of UIN Walisongo Semarang. Jurnal Pendidikan Vokasi, 9(3), 258 - 269. https://doi.org/10.21831/jpv.v9i3.26948.

Fauzi, H. A., Komalasari, K., \& Malik, Y. (2017). Utilization of Audio Visual Media to Improve Student Learning Result in IPS Learning. International Journal Pedagogy of Social Studies, 2(1), 88-103. https://doi.org/https://doi.org/10.17509/ijposs.v2i1.8666.

Fiana, R. O., Relmasira, S. C., \& Hardini, A. T. A. (2019). Perbedaan Penerapan Model Project Based Learning Dan Problem Based Learning Terhadap Hasil Belajar Matematika Kelas 4 SD. Jurnal Basicedu, 3(1), 157 - 162. https://doi.org/10.31004/basicedu.v3i1.95.

Gunawan, G., Sahidu, H., Harjono, A., \& Suranti, N. M. Y. (2017). The effect of project based learning with virtual media assistance on student's creativity in physics. Jurnal Cakrawala Pendidikan, 1(2). https://doi.org/https://doi.org/10.21831/cp.v36i2.13514.

Hamdi, Halim, A., \& Pontas, K. (2015). Pengembangan Dan Penerapan Modul Pembelajaran Materi Teori Dasar Bentuk Muka Bumi Untuk Meningkatkan Kognitif Mahasiswa Pendidikan MIPA FKIP UNIGHA $\begin{array}{lllll}\text { Sigli. Jurnal Pendidikan } & \text { Sains }\end{array}$ http://www.jurnal.unsyiah.ac.id/JPSI/article/view/7676.

Ismi, L. (2019). Efektivitas Pengembangan E-Modul Project Based Learning Pada Mata Pelajaran Instalasi. Jurnal Imiah Pendidikan Dan Pembelajaran, 3(3), 306-315. https://doi.org/10.23887/jipp.v3i3.21840. 306-309.

Jannah et al. (2021). Efektivitas Penggunaan E-Modul Terhadap Hasil Belajar Kognitif Pada Materi Sistem Pencernaan Manusia di Madrasah Tsanawiyah. Jurnal Basicedu, 5(2), 1060-1066. https://doi.org/10.31004/basicedu.v5i3.952.

Khofiyah, H. N., Santoso, A., \& Akbar, S. (2019). Pengaruh Model Discovery Learning Berbantuan Media Benda Nyata terhadap Kemampuan Berpikir Kritis dan Pemahaman Konsep IPA. Jurnal Pendidikan: Teori, Penelitian, Dan Pengembangan, 4(1), 61-67. https://doi.org/10.17977/jptpp.v4i1.11857.

Kiong, T. T., Yunos, J. M., Mohammad, B., Othman, W., Heong, Y. M., \& Mohamad, M. M. (2012). The Development and Implementation of Buzan Mind Mapping Module. Procedia - Social and Behavioral Sciences, 64. https://doi.org/https://doi.org/10.1016/j.sbspro.2012.11.464. 
Kuncahyono. (2018). Pengembangan E-Modul (Modul Digital) dalam Pembelajaran Tematik di Sekolah Dasar. Journal of Madrasah Ibtidaiyah Education, 2(2), 121. https://doi.org/http://dx.doi.org/ 10.32934/jmie.v2i2.75 Copyright.

Logan, R. M., Johnson, C. E., \& Worsham, J. W. (2021). Development of an e-learning module to facilitate student learning and outcomes. Teaching and Learning in Nursing, 16(2), 139-142. https://doi.org/10.1016/j.teln.2020.10.007.

Lutfi, Ismail, \& Azis, A. A. (2017). Pengaruh project based learning terintegrasi stem terhadap literasi sains , kreativitas dan hasil belajar peserta didik. Prosiding Seminar Nasional Biologi Dan Pembelajarannya, 189-194.

Mahendra, E. (2017). Project Based Learning Bermuatan Etnomatematika Dalam Pembelajar Matematika. Jurnal Pendidikan Indonesia, 6(1). https://doi.org/http://dx.doi.org/10.23887/jpiundiksha.v6i1.9257.

Mardati, Asih, \& Wangit. (2015). Pengembangan Media Permainan Kartu Gambar Dengan Teknik Make A Match Untuk Kelas 1 SD. Jurnal Prima Edukasia, 3(2), 120- 132. https://doi.org/https://doi.org/10.21831/jpe.v3i2.6532.

Marlani, L., \& Prawiyogi, A. G. (2019). Penerapan Model Pembelajaran Project Based Learning Untuk Meningkatkan Keterampilan Menulis Puisi Di Sekolah Dasar. Al-Aulad: Journal of Islamic Primary Education, 2(1). https://doi.org/10.15575/al-aulad.v2i1.4427.

Maulana, H. A., \& Hamidi, M. (2020). Persepsi Mahasiswa terhadap Pembelajaran Daring pada Mata Kuliah Praktik di Pendidikan Vokasi. Equilibrium: Jurnal Pendidikan, 8(2), 224-231. https://doi.org/10.26618/equilibrium.v8i2.3443.

Merchie, E., \& Keer, H. Van. (2016). Mind mapping as a meta-learning strategy: Stimulating pre-adolescents' text-learning strategies and performance? Contemporary Educational Psychology, 46. https://doi.org/https://doi.org/10.1016/j.cedpsych.2016.05.005.

Nurcahyo, R. W., \& Kartowagiran, B. (2015). Praktik Pengalaman Lapangan dan Dampaknya Terhadap Kompetensi Mahasiswa Program Studi Teknik Informatika dan Komputer. Jurnal Pendidikan Vokasi, 5(2). https://doi.org/10.21831/jpv.v5i2.6418.

Ramli, M. S., \& Tajudin, N. (2021). Analisis keperluan untuk membangunkan Modul Pembelajaran Berasaskan Challenge dalam Mempelajari Matematik bagi murid tingkatan 4. Jurnal Pendidikan Sains \& Matematik Malaysia, 11, 50-58. https://doi.org/10.37134/jpsmm.vol11.sp.5.2021.

Rosciano, A. (2015). The effectiveness of mind mapping as an active learning strategy among associate degree nursing students. Teaching and Learning in Nursing, 10(2). https://doi.org/https://doi.org/10.1016/j.teln.2015.01.003.

Safitri, N. L., Zubaidah, S., \& Kuswantoro, H. (2018). Pengembangan LKS Project Based Learning Berbasis Penelitian Perlakuan Perbedaan Dosis Fosfat pada Genotipe Kedelai. Jurnal Pendidikan: Teori, Penelitian, Dan Pengembangan, 3(4), 518-523. https://doi.org/10.17977/jptpp.v3i4.10813.

Saputro, O. A., \& Rayahu, T. S. (2020). Perbedaan Pengaruh Penerapan Model Pembelajaran Project Based Learning ( Pjbl ) Dan Problem Based Learning ( Pbl ) Berbantuan Media Monopoli. Jurnal Imiah Pendidikan Dan Pembelajaran, 4(1), 185-193. https://doi.org/10.23887/jipp.v4i1.24719.

Setyowati, N., \& Mawardi, M. (2018). Sinergi Project Based Learning dan Pembelajaran Bermakna untuk Meningkatkan Hasil Belajar Matematika. Scholaria: Jurnal Pendidikan Dan Kebudayaan, 8(3), 253263. https://doi.org/10.24246/j.js.2018.v8.i3.p253-263.

Solikin, I. (2018). Implementasi E-Modul pada Program Studi Manajemen Informatika Universitas Bina Darma Berbasis Web Mobile. Jurnal RESTI (Rekayasa Sistem Dan Teknologi Informasi), 2(2), 492497. https://doi.org/10.29207/resti.v2i2.393.

Suastika, I. K., \& Amaylyla. (2019). Pengembangan modul pembelajaran matematika dengan pendekatan kontekstual. Jurnal Pendidikan Matematika Indonesia, 4(2). https://doi.org/https://dx.doi.org/10.26737/jpmi.v4i2.1230.

Sudarmin, S., \& Samini, S. (2016). Efektivitas penggunaan modul terintegrasi etnosains dalam pembelajaran berbasis masalah untuk meningkatkan literasi sains siswa. Unnes Science Education Journal, 4(3). https://doi.org/10.15294/USEJ.V4I3.8860.

Sugiono. (2018). Metode Penelitian Pendididkan Pendekatan Kuantitatif, Kualitatif, dan R\&D. Alfabeta.

Sumarmi, S., \& Rostini, D. (2019). Manajemen Pembelajaran, Kompetensi Lulusan Implementasi Manajemen Pembelajaran Untuk Mempersiapkan Uji Kompetensi. Nusantara Education Review.

Sunismi. (2015). Developing Guided Discovery Learning Materials Using Mathematics Mobile Learning Application As An Alternative Media For The Students Calculus II. Cakrawala Pendidikan, 34(3), 334-346. https://doi.org/10.21831/cp.v3i3.7340.

Triana, D., Anggraito, Y. U., \& Ridlo, S. (2020). Effectiveness of environmental change learning tools based on STEM-PjBL towards 4C skills of students. Journal of Innovative Science Education, 9(2), 181-187. 
https://doi.org/10.15294/JISE.V8I3.34048.

Trianawati. (2019). Pengaruh Model Discovery Learning Berbantuan Media Animasi Terhadap Kompetensi Pengetahuan IPA Siswa Kelas IV SDN Gugus VI Abiansemal Tahun Ajaran 2018/2019. International Journal of Elementary Education, 4. https://doi.org/10.23887/ijee.v4i1.24337.

Utami, T. N., Jatmiko, A., \& Suherman. (2018). Pengembangan Modul Matematika dengan Pendekatan Science, Technology, Engineering, And Mathematics (STEM) pada Materi Segiempat. Jurnal Matematika, 1(2), 165-172. https://doi.org/10.24042/djm.v1i2.2388.

Yusnindar, E. \&. (2015). Pengembangan Modul Berbasis Pendekatan Kontekstual Materi Sistem Koloid untuk Mahasiswa Kimia Dasar II Prodi Pendidikan Kimia. Journal of The Inonesian Society of Intregated Chemistry, 7(1), 1-8. https://doi.org/10.22437/jisic.v7i1.4831. 